\title{
RECYCLING OF AURIFEROUS ORE FLOTATION TAILINGS IN SLAG-ALKALINE CEMENT
}

\author{
Volodimir Gots \\ Department of Technology of Building Structures and Products \\ Kyiv National University of Construction and Architecture \\ 31 Povitroflotskii ave., Kyiv, Ukraine, 03680 \\ volodimir.gots@ukr.net \\ Oles Lastivka \\ Department of Technology of Building Structures and Products \\ Kyiv National University of Construction and Architecture \\ 31 Povitroflotskii ave., Kyiv, Ukraine, 03680 \\ oles.lastivka@gmail.com \\ Elizabeth Volunska \\ Department of Technology of Building Structures and Products \\ Kyiv National University of Construction and Architecture \\ 31 Povitroflotskii ave., Kyiv, Ukraine, 03680 \\ elizabeth13n@gmail.com \\ Oleksandr Tomin \\ Department of Technology of Building Structures and Products \\ Kyiv National University of Construction and Architecture \\ 31 Povitroflotskii ave., Kyiv, Ukraine, 03680 \\ tomin.oleks.93@gmail.com
}

\begin{abstract}
Research analysis aimed at stabilizing processes in industrial waste and other, similar hazardous ion containing materials, shows that these materials can be successfully stabilized, if they are bound as a mineral component in cement. Considering that auriferous ore flotation waste contains heavy metals that are useless for any production and accumulated in dumps, storages and sumps, this impairs the ecology of the country. This is why current study is conducted on recycling of auriferous ore flotation tailings by binding it as a cement component, which is also can be one of its effective applications. For heavy metal bonds stability evaluation in the composition of the cement matrix, the method of leaching elements by atomic spectroscopy was applied.

According to the research it was found that application of slag-alkaline viscid systems for recycling of auriferous ore dump flotation tailings provides considerable advantages over traditional Portland cement systems based on PC I-500. It was shown that along with the physical blocking in the artificial stone matrix, based on slag-alkaline viscid systems, elements of heavy metals were also bound chemically as a part of structure-forming compounds. In this regard use of auriferous ore dump flotation tailings (10...30 \%) in the compound of slag-alkaline cement results in the prolonged solidification and provides the same level of cement stone durability as the check sample compound.

Keywords: auriferous ore flotation waste, slag-alkaline cement, Portland cement, heavy metals, leaching, solidification terms, durability.

\section{Introduction}

Thorough studies in the field of construction materials science allow conducting a rational disposal of technological waste, for which one of the main sources is mining industry. Through the use of secondary material resources it is possible to solve a number of important tasks such as saving raw materials, preventing water, soil and air pollution, reduction of energy consumption in construction materials production. However, despite the environmental hazard of mining industry waste, annual waste production in Ukraine reaches nearly 500 million tons [1]. Nevertheless, there are still no defined practical solutions for the effective waste disposal.
\end{abstract}


Given great variety of mining industrial waste types, special attention should be paid to auriferous ore flotation tailings, main part of which is never used and accumulated in dumps, storages and sumps. Considering that the gold percentage is distributed very unevenly and ranges from 10 to $100 \mathrm{gr} / \mathrm{ton}$, it influences the accumulation of the auriferous ore dump flotation tailings [2-5]. Until present, the main treatment method for this waste type is ground storing which causes adverse ecological situations that manifest themselves in deterioration of sanitary and hygienic conditions, violation and change of natural landscapes and loss of natural resources.

It should be also mentioned that this waste type has heavy metals in its composition: lead, manganese, zinc, Fe, which by decision of the UNECE are attributed to the most hazardous group $[6,7]$ and, respectively, one of the priority targets for control and regulation. Affected by the atmospheric precipitations and weathering, leaching of heavy metals takes place from the auriferous ore flotation tailings, which results in polluting materials emission into the air, water and soil [8,9]. This is why it is a priority task to look for technical and technological solutions in the area of the abovementioned waste utilization into environment friendly products, including construction materials.

Certain proposals are known of waste disposal that include heavy metals in construction materials production using classical cement systems [10-13] which have low efficiency due to the low fixation stability in the artificial stone compound and as a result have limited application ability. The future-proof solution for the auriferous ore flotation waste disposal in the composition of construction materials and heavy metals localization is the use of slag-alkaline cement as a viscid materials developed by Scientific-Research Institute for Binders and Materials (SRIB\&M). In this way, known solutions [14-17] show quite high localization reliability of radioactive, including heavy, metals in the composition of slag-alkaline cements that allow fixing the elements reliably inside the material structure at both physical and chemical level. Known data of foreign researchers $[18,19]$ also show high efficiency and reliability of heavy metals localization in the compound of slag-alkaline viscid systems.

This is why the current study is conducted on recycling of auriferous ore flotation tailings by binding it as a cement component, which also can be one of the effective applications for this type of waste.

\section{Raw Materials and Research Methods}

As a test systems during research of structuring processes in the "slag-alkaline cementheavy metals" system, a slag-alkaline viscid material was used based on the blast furnace granulated slag from Ilyich Iron and Steel Works of Mariupol with $\mathrm{M}_{\mathrm{o}}=1.1$ and the alkaline component in the form of sodium metasilicate pentahydrate that was inserted into cement compound in a dispersed form. During production of slag-alkaline cement, sodium lignosulfonate was also additionally inserted for providing acceptable solidification times. $\mathrm{Fe}_{3} \mathrm{O}_{4}, \mathrm{MnO}_{2}, \mathrm{~Pb}_{2} \mathrm{O}_{3}$ were used at $10 \mathrm{wt} . \%$ percentage in viscid composition as a heavy metals compounds.

Auriferous ore flotation enrichment dump tailings (DT) from the Sauliak field were used as a real waste containing heavy metals.

Chemical composition of the raw materials is shown in Table $\mathbf{1 .}$

Table 1

Chemical Composition of the Raw Materials

\begin{tabular}{ccccccccccc}
\hline \multirow{2}{*}{ Ingredients } & \multicolumn{10}{c}{ Oxides percentage, wt. \% } \\
& $\mathbf{S i O}_{2}$ & $\mathbf{A l}_{2} \mathbf{O}_{3}$ & $\mathbf{M g O}$ & $\mathbf{C a O}$ & $\mathbf{N a}_{\mathbf{2}} \mathbf{O}$ & $\mathbf{S O}_{3}$ & $\mathbf{F e}_{\mathbf{3}} \mathbf{O}_{4}$ & $\mathbf{M n O}_{2}$ & $\mathbf{P b O}$ & $\mathbf{0 x . ~ a d m . ~}$ \\
\hline Clinker & 21.3 & 5.7 & 1.2 & 64.9 & 0.3 & 0.86 & - & - & - & 0.12 \\
Slag & 39.0 & 5.9 & 5.82 & 47.3 & 0.6 & 1.54 & - & - & - & - \\
Dump tailings & 60.05 & 17.0 & 4.28 & 7.47 & 3.74 & 1.1 & 7.44 & 0.8 & 0.2 & -
\end{tabular}

The processes of structuring viscid compositions in the presence of heavy metals were studied with the help of physical and chemical methods of analysis: X-ray analysis by diffractometer 
DRON-3M and differentially thermal analysis (DTA) by derivatograph of R. Paulik, J. Paulik, and L. Erdey system, MOM (Budapest). The heavy metals bonds stability in the compound of cement matrix was studied through method of leaching elements by atomic spectroscopy. Compressive strength of cement $(40 \times 40 \times 160 \mathrm{~mm})$ was determined according to DSTU B V.2.7-187:2009. The conditions of samples solidification were normal: temperature $\mathrm{t}=20 \pm 2{ }^{\circ} \mathrm{C}$, moisture $\mathrm{W}=95 \pm 5 \%$.

\section{Research Findings}

According to the physical and chemical research studies (Fig. 1, cur. 1), phased compound of hydration product of the slag-alkaline cement stone after 28 days of solidification was presented mainly by the calcium silicate hydrate CSH (B) $(\mathrm{d}=0.289 ; 0.210 ; 0.183 \mathrm{~nm})$, hydro nepheline $(\mathrm{d}=0.368 ; 0.279 ; 0.213 \mathrm{~nm})$ and inclusions of quartz $(\mathrm{d}=0.429 ; 0.334 ; 0.228 \mathrm{~nm})$. Presence of new compositions stated above was confirmed by the data from DTA through indexes of internal effects in the range of temperatures $130 \ldots 145^{\circ} \mathrm{C}$ and external effects in the range $835 \ldots 840{ }^{\circ} \mathrm{C}$, typical for the calcium silicate hydrate. Hydro nepheline synthesis was confirmed by the presence of internal effect at the temperatures of $570 \ldots 575^{\circ} \mathrm{C}$.
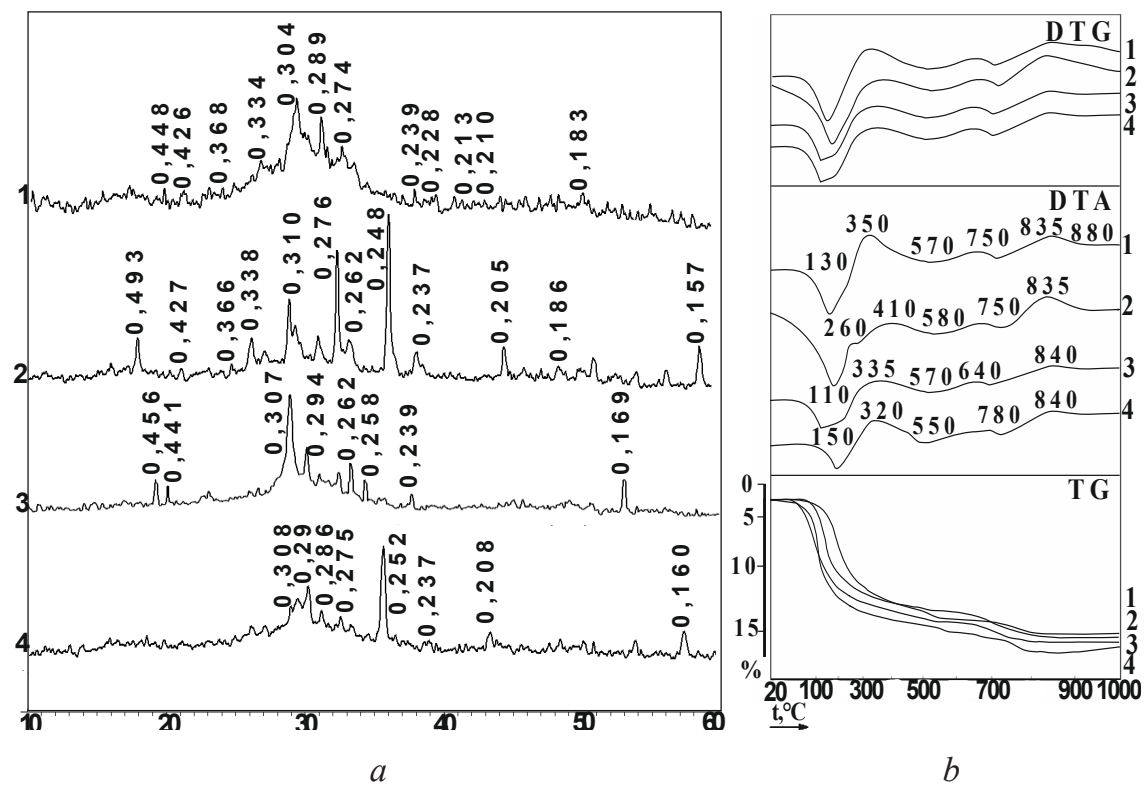

Fig. 1. Results of X-ray $(a)$ and DTA $(b)$ for hydrated slag-alkaline compositions after 28 days of solidification: 1 - without admixtures; 2 - with admixture of lead; 3 - with admixture of Fe; 4 - with admixture of manganese

$\mathrm{PbO}$ were inserted in the slag-alkaline cement as a compound of heavy metal and it showed that the number of silicate hydrate bonds was reduced. There are the following bonds present among crystal compositions (Fig. 1, cur. 2) $\mathrm{Pb}_{2}\left(\mathrm{CO}_{3}\right) \cdot(\mathrm{OH})_{6} \mathrm{O}(\mathrm{d}=0.427 ; 0.338 ; 0.262 \mathrm{~nm})$, $3 \mathrm{PbCO}_{3} \cdot 2 \mathrm{~Pb}(\mathrm{OH})_{2} \cdot \mathrm{H}_{2} \mathrm{O}(\mathrm{d}=0.426 ; 0.368 ; 0.334 ; 0.248 \mathrm{~nm})$ and $5 \mathrm{CaO} \cdot \mathrm{Pb}_{2} \mathrm{O}_{5} \cdot \mathrm{SiO}_{4}$, which shows that the chemical connection between heavy metal element and cement has been established. Besides, it was noticed that there is a non-hydrated output element $\left(\mathrm{PbO}_{2}\right)(\mathrm{d}=0.276 ; 0.205 ; 0.157)$ present in the structure of artificial stone. Presence of $\mathrm{Pb}_{2}\left(\mathrm{CO}_{3}\right) \cdot(\mathrm{OH})_{6} \mathrm{O}$ is confirmed by DTA through indexes of internal effects at temperature of $260{ }^{\circ} \mathrm{C}$.

In case of using $\mathrm{Fe}_{3} \mathrm{O}_{4}$ (Fig. 1, cur. 3) the chemistry of interaction of current metal with silicate and aluminum-silicate component of the cement in alkaline environment takes place in the following order: as a result of hydrolysis Fe transformed into trivalent form in gear-type coordination and plays a role of an amphoteric oxide continuing to form a new composition of nontronite $\mathrm{Na}_{0.5} \mathrm{Fe}_{2} \mathrm{Si}_{3} \mathrm{AlO}_{10}(\mathrm{OH})_{2} \cdot 4 \mathrm{H}_{2} \mathrm{O}(\mathrm{d}=0.456 ; 0.262 ; 0.169)$ and ferrihalloysite $(\mathrm{Al}, \mathrm{Fe})_{2} \mathrm{O}_{3} 2 \mathrm{SiO}_{2} \cdot 2 \mathrm{H}_{2} \mathrm{O}(\mathrm{d}=0.441 ; 0.258 ; 0.239)$. Nontronite synthesis is confirmed by the presence of internal effect at temperature of $110{ }^{\circ} \mathrm{C}$ and external effect at temperature $640{ }^{\circ} \mathrm{C}$. 
After inserting of heavy metal compound $\mathrm{MnO}_{2}$ in the slag-alkaline cement (Fig. 1, cur. 3), phased composition of the artificial stone hydration products after 28 days of solidification is characterized by additional presence of rhodonide $-\mathrm{MnO} \cdot \mathrm{SiO}_{2}(\mathrm{~d}=0,308 ; 0,293 ; 0,275 ; 0,252)$ and pumpellyite $(d=0,286 ; 0,208 ; 0,160)$, that also shows the ability of the mentioned heavy metal to participate in the process of structuring of alkaline viscid compositions. Presence of rhodonide is confirmed by DTA through the indexes of internal effects at the temperature of $780{ }^{\circ} \mathrm{C}$.

The reliability of the chemical bonds of heavy metal elements in structuring compounds of the artificial stone based on alkaline viscid systems was studied through "slag-alkaline cement + dump tailings". "PC I-500 + dump tailings" was also studied (Table 2) as a system for comparison. Chemical stability of the compounds was defined by leaching the metals in a contact environment. Distilled water, saline ( $\mathrm{pH}-11)$ and acid $(\mathrm{pH}-3)$ solution was used as a contact environment. Before testing the samples, cylinders $(\mathrm{h}=60, \mathrm{~d}=30 \mathrm{~mm})$ after 28 days of solidification, were put in contact with the environments at the rate 1 to 10 accordingly sample volume to a contact environment volume. After that, the samples were exposed during 7, 14, 28 days. For quantitative evaluation of the leaching grade of the heavy metal, the method of atomic spectroscopy was applied.

Processing and analysis of the sample, containing dump tailings, leaching results (contact environment distilled water) showed the high grade of chemical binding the Mn, Fe elements in the "slag-alkaline cement + dump tailings" (№ 1) where percentage of dump tailings was $20 \%$ (Table 2). After increasing the percentage of dump tailings up to $(30 \%)$ in the cement it showed a partial leaching of Fe $(0,05 \mathrm{mg} / \mathrm{l})$. On the other hand, when dump tailings were used as a part of PC I-500 (№ 3), it showed leaching both Mn (0,01 mg/l) and Fe (0,3 mg/l), that proves the low level of chemical binding of these elements.

After changing the contact environment (saline or acid solution), it showed quite intense leaching of heavy metals in both Portland (№ 3) and slag-alkaline (№ 1, 2) cement systems. However, the heaviest was leaching noticed in the "PC I-500 + dump tailings" system. In this way, during the use of dump tailings in compound of PC I-500 (№ 3), it showed leaching on 28-th day (saline contact environment), of both $\mathrm{Mn}(0.28 \mathrm{mg} / \mathrm{l})$ and $\mathrm{Fe}(3.9 \mathrm{mg} / \mathrm{l})$, which is accordingly $100 \%$ and $78 \%$ more than "slag-alkaline cement + dump tailings (20\%)" system - Mn (0.14 mg/l), Fe (2.2 mg/l).

With replacement of the contact environment from saline to acid solution, leaching of heavy metals increases. However, leaching on 28-th day of both $\mathrm{Mn}(36.7 \mathrm{mg} / \mathrm{l})$ and $\mathrm{Fe}(253 \mathrm{mg} / \mathrm{l})$ in "PC I-500 + dump tailings" system is $130 \%$ greater and relatively $60 \%$ greater than "slag-alkaline cement + dump tailings" system as well.

Table 2

Intensity of Leaching of Heavy Metals from Viscid Compounds Containing Dump Tailings

\begin{tabular}{|c|c|c|c|c|c|c|c|c|c|c|}
\hline \multirow[b]{2}{*}{ № } & \multicolumn{4}{|c|}{ Component composition of cement, $\%$ wt. } & \multicolumn{3}{|c|}{ Leaching Mn, mg/l, days } & \multicolumn{3}{|c|}{ Leaching Fe, mg/l, days } \\
\hline & Slag & PC I-500 & $\begin{array}{c}\text { Dump } \\
\text { tailings }\end{array}$ & $\mathrm{Na}_{2} \mathrm{SiO}_{3} \times 5 \mathrm{H}_{2} \mathrm{O}$ & 7 & 14 & 28 & 7 & 14 & 28 \\
\hline \multicolumn{11}{|c|}{ Distilled water } \\
\hline 1 & 80 & - & 20 & 6 & 0 & 0 & 0 & 0 & 0 & 0 \\
\hline 2 & 70 & - & 30 & 6 & 0 & 0 & 0 & 0 & 0 & 0.05 \\
\hline 3 & - & 80 & 20 & - & 0.01 & 0.01 & 0.02 & 0 & 0.2 & 0.3 \\
\hline \multicolumn{11}{|c|}{ Saline solution } \\
\hline 1 & 80 & - & 20 & 6 & 0.05 & 0.08 & 0.14 & 1.2 & 1.7 & 2.2 \\
\hline 2 & 70 & - & 30 & 6 & 0.12 & 0.14 & 0.20 & 2.3 & 2.3 & 3.1 \\
\hline 3 & 80 & 80 & 20 & - & 0.18 & 0.22 & 0.28 & 2.7 & 3.0 & 3.9 \\
\hline \multicolumn{11}{|c|}{ Acid solution } \\
\hline 1 & 80 & - & 20 & 6 & 10.7 & 11.8 & 15.7 & 13.7 & 120 & 159 \\
\hline 2 & 70 & - & 30 & 6 & 15.5 & 20.6 & 30.5 & 25.5 & 149 & 205 \\
\hline 3 & 80 & 80 & 20 & - & 19.8 & 28.5 & 36.7 & 36.7 & 196 & 253 \\
\hline
\end{tabular}

In this way, data on participation of the studied heavy metals in structuring of artificial stone bindings was obtained, also it showed the reliability of binding the target elements in slag-alkaline 
compound in comparison with the system based on PC I-500 cement. After replacement of the contact environment (saline or acid solution), leaching of heavy metals increased.

Studying of the cement properties showed that inserting dump tailings into the slag-alkaline cement composition (Fig. 2) allowed extending initial setting time and provide strength of viscid compositions at the level of the check sample compound. In this way, the insertion of admixture from 10 to $30 \%$ extends the initial setting time from 55 to 70 minutes and provides the early obtaining of branded cement strength at the level of the check sample compound: after 2 days, dump tailing cement compressive strength reaches 17.6...18.6 MPa, after 28 days - 39.9...41.7 MPa. There is a check sample compound compressive strength for comparison: after 2 days of solidification - $18.3 \mathrm{MPa}$, after 28 days $-41.4 \mathrm{MPa}$.

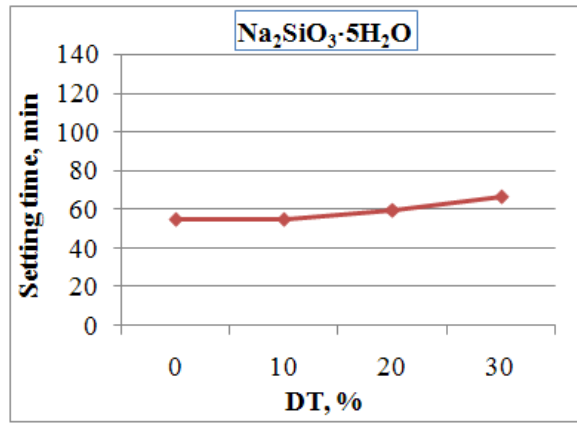

$a$

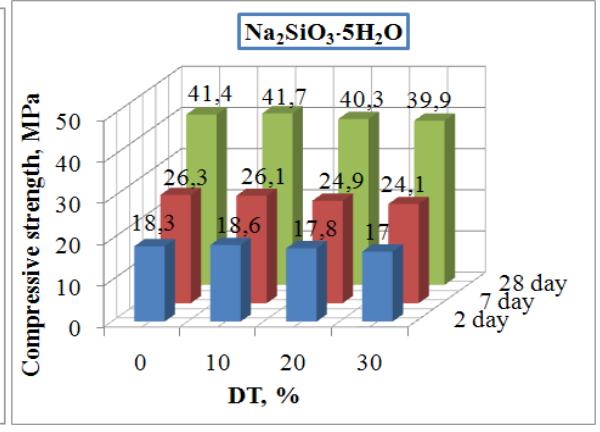

$b$

Fig. 2. Change of initial setting time and compressive strength of slag-alkaline cement (alkaline component $-\mathrm{Na}_{2} \mathrm{SiO}_{3} \cdot 5 \mathrm{H}_{2} \mathrm{O}$ ) that has a dump tailings admixture

At the same time insertion of dump tailings into PC I-500 composition (Fig. 3) results in the extension of the solidification times and reduction of the cement stone durability.

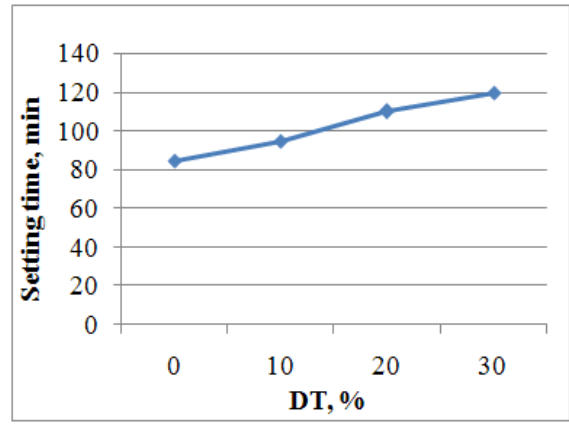

$a$

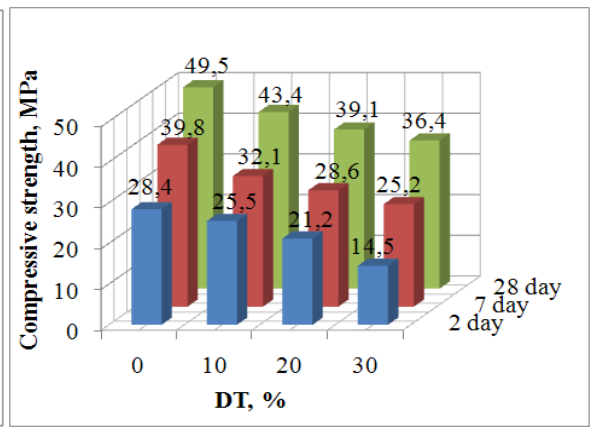

$b$

Fig. 3. Change of initial setting time and compressive strength of PC I-500 cement that has a dump tailings admixture

When dump tailings percentage in the PC I-500 composition present is $10 \%$, it shows the extension of the solidification times and reduction of the cement activity in comparison to the system with no admixture. With the increasing of the admixture percentage up to $20 \%$, the early and the branded strength of viscid compositions are both reduced after 2 days of solidification and reach $21.1 \mathrm{MPa}$, after 28 days $39.1 \mathrm{MPa}$. There is a check sample compound compressive strength for comparison: after 2 days of solidification - 28.4 MPa, after 28 days $-49.5 \mathrm{MPa}$.

\section{Conclusions}

1. The obtained findings on the use of slag-alkaline viscid systems for auriferous ore flotation waste disposal (recycling) show their considerable advantages over the traditional Portland cement systems based on PC I-500. It showed that along with the physical blocking in the matrix of 
the artificial stone based on slag-alkaline viscid systems, heavy metals elements are bound chemically in the composition of structuring compounds.

2. Compositions of slag-alkaline cement were developed, containing auriferous ore flotation enrichment dump tailings in the range of $10 . . .30 \%$, which upon investigated properties meets the requirements of DSTU B.V.2.7-181:2009 that refer to alkaline cements of M400 types and can be recommended for production of concretes on their basis.

\section{References}

[1] Khiljchevsjkyj, V. K. (2007). Vidkhody vyrobnyctva i spozhyvannja ta jikh vplyv na grunty i pryrodni vody. Vydavnycho-polighrafichnyj centr, Kyjivsjkyj universytet, 152.

[2] Smyrnov, V. O., Bilecjkyj, V. S. (2010). Flotacijni metody zbaghachennja korysnykh kopalyn. Donecjk: Skhidnyj vydavnychyj dim, 496.

[3] Coetzee, H., Winde, F. (2006). An Assessment of Sources, Pathways, Mechanisms and Risks of Current and Potential Future Pollution of Water and Sediments in GoldMining Areas of the Wonderfonteinspruit Catchment: WRC Report No. 1214/1/06, Pretoria: Water Research Commission (WRC).

[4] Banister, S., van Biljon, M., Pulles, W. (2002). Development of appropriate procedures for water management when planning underground mine closure - A regional approach using Gold mining as a case study In: Proceedings of the WISA Mine Water division - Mine closure conference, 238-242.

[5] Pulles, W, Banister, S., Van Biljon, M. (2005). The development of appropriate procedures towards and after closure of underground gold mines from a water management perspective. WRC report no 1215/1/05.

[6] Dyrektyva 2001/80/JeS Jevropejsjkogho parlamentu ta rady. (2010). Obmezhennja vykydiv dejakykh zabrudnjujuchykh rechovyn v atmosferu z velykykh spaljuvaljnykh ustanovok, 25.

[7] Hjelmar, O., Holm, J., Hansen, J. G., Dahlstrøm, K. (2005). The European criteria for acceptance of waste at landfills: Implementation of Council Decision 2003/33/EC in Denmark, The 1st International on Engineering for Waste Treatment, WasteEng 05. Albi, France, 46-53.

[8] Klade, M. (2000). Survey and assessment concerning the environmental impact of waste materials produced in the exploration, extraction and processing of mineral resources. Institute Bergbaukunde, Bergtechnik und Bergwirtschaft, 142-154.

[9] Ritcey, G. M. (1989). Tailings Management Problems and solutions in the mining industry.

[10] Patent USA No 4116705, (1974). Sposob obezvrezhyvanyja otkhodov, 5.

[11] Paljghunov, P. P., Sumarokov, M. V. (1990). Utylyzacyja promushlennukh otkhodov. Moscow: strojyzdat, 203-207.

[12] Matheis, G., Jahn, S., Marquardt, R., Schreck, P. (1999). Mobilisation of heavy metals in mining and smelting heaps, Kupferschiefer district, Mansfeld, Germany, Chronique de la recherche miniere, 534, 87-94.

[13] DSTU B V. 2.7. 181:2009. Cementy luzhni. Tekhnichni umovy. Kyiv: Minreghion Ukrajiny.

[14] Krivenko, P., Petropavlovsky, O., Gelevera, A., Jukov, N. (2005). Immobilizing properties of alkaline cementitious systems. 2nd International Symposium Non-traditional cement \& concrete, Brno, 613-626.

[15] Skurchynskaja, Zh. V., Kryvenko, P. V., Lavrynenko, L. V., Samojlenko, Ju. Y., Makeeva, Y. N. (1993). Utylyzacyja ghaljvanycheskykh shlamov pry proyzvodstve shlakoshhelochnukh vjazhushhykh. Cement, 3, 37-39.

[16] Kryvenko, P. V., Skurchynskaja, Z. V., Ghelevera, A. G. (1997). Utylyzacyja y ymmobylyzacyja razlychnukh toksychnukh otkhodov, ekotekhnologhyy y resursosberezhenye, 5, 62-66.

[17] Kryvenko, P. V. (1997). Ymmobylyzacyja vrednukh, toksychnukh, radyoaktyvnukh otkhodov y zaghrjaznennukh zemelj, ykh soderzhashhykh, v myneralopodobnue kompaundu, Tr. yndyjskoj gheotekhn. konf., Yndyja, Baroda, dek, 43-51.

[18] Malolepszy, J., Deja, J. (1994). Immobilization of heavy metal ions by the alkali activated slag cementitious materials. Environmental Aspects of Construction with Waste Materials, 519-524. doi: 10.1016/ s0166-1116(08)71484-5

[19] Van Jaarsveld, J. G. S., Van Denventer, J. S. J. (1999). The effect of metal contaminants on the formation properties of waste based Geopolymers. Cement and Concrete Research, 29 (8), 1189-1200. doi: 10.1016/s0008-8846(99)00032-0 